Jurnal Sastra Indonesia

http://journal.unnes.ac.id/sju/index.php/isi

\title{
HUMANISME DALAM CERITA RAKYAT DI KABUPATEN PATI
}

\author{
Nurul Huda ${ }^{\bowtie}$, U'um Qomariyah, Mukh Doyin
}

Jurusan Bahasa dan Sastra Indonesia, Fakultas Bahasa dan Seni, Universitas Negeri Semarang, Indonesia

\begin{tabular}{l}
\hline Info Artikel \\
\hline Sejarah Artikel: \\
Diterima Mei 2018 \\
Disetujui Agustus 2018 \\
Dipublikasikan November \\
2018
\end{tabular}

Keywords:

humanism, folklore, Pati.

\begin{abstract}
Abstrak
Penelitian ini bertujuan untuk mendeskripsikan bentuk-bentuk etika humanisme sastra profetik dan faktor-faktor yang melatarbelakangi tokoh beretika humanisme di dalam cerita rakyat di Kabupaten Pati. Pendekatan yang dilakukan dalam penelitian ini adalah pendekatan folklor, yaitu pendekatan yang mempelajari kebudayaan suatu masyarakat yang secara khusus disebarkan secara lisan. Pendekatan folklor digunakan untuk meneliti cerita rakyat di Kabupaten Pati yang kemudian dianalisis menggunakan teori sastra profetik khususnya etika humanisme. Metode yang digunakan dalam penelitian ini adalah metode deskriptif kualitatif. Data di dalam penelitian ini adalah cerita rakyat di Kabupaten Pati yang di dalamnya terkandung etika-etika humanisme. Sumber data penelitian ini terdiri atas dua sumber yakni sumber tulis dan sumber lisan. Sumber tulis dalam penelitian ini yaitu kumpulan cerita rakyat Kabupaten Pati yang terdapat dalam buku berjudul Sejarah Masyarakat Pati: Dari Tradisi Lisan Menuju Sejarah Kritis dan Sunan Prawoto Cucu Sunan Kali Jaga. Adapun sumber lisan dari penelitian ini yaitu hasil wawancara yang dilakukan oleh peneliti kepada beberapa narasumber untuk memperoleh cerita rakyat yang tidak ada di dalam sumber tulis tersebut. Pengumpulan data yang dilakukan dalam penelitian ini menggunakan beberapa teknik yaitu observasi, dokumentasi, dan perekaman. Hasil penelitian menunjukkan bahwa bentuk etika humanisme yang terdapat dalam cerita rakyat di Kabupaten Pati merupakan wujud saling menghormati di antara sesama manusia, serta saling mengajak ke dalam kebaikan. Para tokoh yang melakukan etika humanisme dipengaruhi oleh dua faktor, yaitu faktor internal dan faktor eksternal seperti faktor desakan situasi dan lingkungan.
\end{abstract}

\begin{abstract}
This study aims to describe the forms of ethical humanist ethical literature and the factors behind the ethical character of humanism in folklore in Pati Regency. The approach taken in this research is the folklore approach, which is the approach that studies the culture of a society that is specifically spread orally. The folklore approach is used to examine folklore in Pati Regency which is then analyzed using prophetic literary theory, especially ethics of humanism. The method used in this research is descriptive qualitative method. The data in this research is folklore in Pati Regency which contains humanism ethics. The data source of this research consists of two sources namely the source of writing and oral sources. Sources of writing in this study is a collection of folklore Pati Regency which is contained in a book entitled Sejarah Masyarakat Pati: Dari Tradisi Lisan Menuju Sejarah Kritis and Sunan Prawoto Cucu Sunan Kali Jaga. The oral source of this research is the results of interviews conducted by researchers to some resource persons to obtain folklore that is not in the source of the write. Data collection conducted in this research using several techniques that are observation, documentation, and recording. The results showed that the
\end{abstract}


Nurul Huda/ Jurnal Sastra Indonesia 7 (3) (2018)

ethical form of humanism contained in folklore in Pati Regency is a manifestation of mutual respect among fellow human beings, and mutual invite to the good. The figures who do ethics of humanism are influenced by two factors, namely internal factors and external factors such as the situation and environmental pressures.

(C) 2018 Universitas Negeri Semarang

$\triangle$ Alamat korespondensi:

ISSN 2252-6315

Gedung B1 Lantai 1 FBS Unnes

Kampus Sekaran, Gunungpati, Semarang, 50229

E-mail: mailto:nurul_vario95@yahoo.com 


\section{PENDAHULUAN}

Dewasa ini budaya lokal yang menjadi ciri khas dan jiwa bangsa semakin terkikis oleh budaya dari luar. Hal tersebut terjadi karena arus globalisasi memudahkan budaya-budaya asing masuk dan berbaur dengan budaya lokal, yang disadari atau tidak dapat mempengaruhi tatanan budaya bangsa.

Era yang memberi fasilitas kemudahan dalam segala hal seperti di bidang informasi, komunikasi, dan transportasi tersebut bukan berarti tidak memiliki dampak. Baik disadari atau tidak, kemudahan dalam beraktivitas yang segalanya bisa dipenuhi oleh diri sendiri tersebut tentu akan memunculkan dampak negatif bagi individu masing-masing. Salah satunya yaitu menjadikan manusia sebagai pribadi yang individualistis.

Individualistis merupakan sikap yang lebih mementingkan kepentingan pribadi daripada kepentingan bersama. Untuk memenuhi kepentingannya tersebut, golongan manusia individualistis tidak memperdulikan dampak yang akan dirasakan oleh orang-orang di lingkungan sekitarnya. Sehingga muncullah istilah dehumanisasi, yaitu hilangnya rasa kemanusiaan. Mengangkat kembali budaya lokal yang mampu mengembalikan dan menguatkan karakter bangsa saat ini sangat perlu dilakukan. Salah satunya ialah malalui kajian etika profetik terhadap cerita rakyat.

Cerita rakyat merupakan salah satu aset dalam khasanah kebudayaan nasional yang menjadi kebanggaan bangsa dengan budayanya yang beraneka ragam. Cerita-cerita rakyat yang berkembang dalam kelompok masyarakat tersebut sebetulnya mengandung nilai-nilai yang mampu menjadi kontrol aturan yang tidak tertulis dalam suatu masyarakat. Pembentukan mental dan karakter bisa mulai diajarkan pada anak-anak melalui cerita-cerita rakyat yang berkembang dilingkungan terdekatnya, baik melalui tokoh-tokoh yang dihadirkan, maupun nilai-nilai moral, sosial, dan religius yang terkandung dalam cerita rakyat tersebut. Mengenalkan nilai-nilai cerita rakyat ini bisa dilakukan dengan berbagai cara. Bisa dilakukan melalui penyampaian secara lisan seperti mendongeng kepada anak-anak, pembukuan cerita-cerita rakyat sebagai bahan bacaan untuk masyarakat, dan penelitian terhadap cerita-cerita rakyat untuk mempertajam kandungan nilai agar dapat digunakan sebagai bahan referensi.

Dalam penelitian ini, dilakukan penelitian tentang cerita rakyat berdasarkan kajian sastra profetik. Kuntowijoyo (2013) menjelaskan bahwa nilai-nilai profetik bersumber dari etika profetik yang terdapat dalam kitab suci al Quran, Surah Ali-Imron, ayat 110: "Kamu adalah umat terbaik yang dilahirkan untuk manusia, menyuruh kepada makruf, dan mencegah kemungkaran, dan beriman kepada Allah". Dari ayat tersebut selanjutnya Kuntowijoyo menyatakan ada tiga nilai profetik, yaitu amar makruf (menyuruh kebaikan, humanisasi), nahi munkar (mencegah kemungkaran, liberasi), dan tukminu billah (beriman kepada Tuhan, transendental).

Dalam penelitian ini, peneliti memfokuskan pada penelitian etika profetik humanisasi dalam cerita rakyat. Dimensi etika profetik humanisasi yaitu mengajarkan nila-nilai kemanusiaan, bagaimana memanusiakan manusia, melampaui keegoan, keangkuhan dan kekerasan terhadap manusia lain.

Penelitian ini melakukan kajian sastra profetik yang berfokus pada etika humanisme di dalam cerita rakyat di Kabupaten Pati. Persoalan yang terjadi dalam cerita rakyat di Kabupaten Pati meliputi persoalan keagamaan, peperangan, percintaan, hingga persoalan hubungan kekeluargaan. Dari persoalan tersebut, cerita rakyat di Kabupaten Pati termasuk ke dalam cerita rakyat beretika profetik. Kemudian jika dilihat lebih dalam lagi dan dihubungkan dengan tradisi yang masih dilestarikan hingga sekarang, persoalanpersoalan tersebut lebih fokus kepada etika humanisme. Hal ini terbukti dari beberapa tradisi seperti Meronan, Selametan, Haul dan Sedekah Bumi yang semuanya bertujuan untuk mengajak dalam kebaikan (etika humanisme) yang sesuai dengan dasar sastra profetik.

Tujuan dari penelitian ini ialah mendeskripsikan bentuk etika humanisme di dalam cerita rakyat di Kabupaten Pati dan mendeskripsikan faktor-faktor yang mempengaruhi tokoh beretika humanisme dalam cerita rakyat di Kabupaten Pati.

Penelitian yang berhubungan dengan humanisme, sastra profetik, dan cerita rakyat sudah pernah dilakukan oleh peneliti-peneliti sebelumnya. Beberapa penelitian tersebut antara lain Saritas (2008), Lukin (2008), Lestari (2009), Prasetyo (2009), Trianton (2013), Qomariyah (2015), Afiyanti (2016). Dari beberapa penelitian tersebut diketahui bahwa penelitian tentang sastra profetik yang fokus kepada etika humanisme terhadap cerita rakyat di Kabupaten Pati diduga belum pernah dilakukan. Selain untuk melawan dehumanisasi, penelitian ini juga akan memberikan sumbangsih bagi ilmu sastra khususnya sastra profetik. Oleh karena itu penelitian ini sangat penting dilakukan. 


\section{METODE PENELITIAN}

Metode yang digunakan dalam penelitian ini adalah metode deskriptif kualitatif. Bogdan dan Taylor (dalam Moleong, 2007:4) menjelaskan, metode kualitatif yaitu prosedur penelitian yang menghasilkan deskripsi berupa kata-kata tertulis atau lisan dari orang-orang dan perilaku yang dapat diamati. Dalam penelitian ini, metode kualitatif digunakan karena metode ini menganalisis subjek atau data yang diteliti tanpa menggunakan penghitungtan angkaangka, sehingga data-data dalam penelitian ini diperoleh tanpa menyajikan grafik atau data angka.

Dalam penelitian ini, peneliti bermaksud menggambarkan atau menguraikan nilai humanisme cerita rakyat di Kabupaten Pati dan faktor yang mempengaruhi tokoh beretika humanisme dalam cerita rakyat di Kabupaten Pati. Dikarenakan penelitian ini bersifat kualitatif, maka penelitian ini menghasilkan data deskriptif analisis, atau dengan kata lain data yang dianalisis dan hasil analisisnya berbentuk deskriptif.

Data di dalam penelitian ini adalah cerita rakyat di Kabupaten Pati yang di dalamnya terkandung etika-etika humanisme. Sumber data penelitian ini terdiri atas dua sumber yakni sumber tulis dan sumber lisan. Sumber tulis dalam penelitian ini yaitu didapat dari buku kumpulan cerita rakyat Kabupaten Pati yang berjudul Sejarah Masyarakat Pati: Dari Tradisi Lisan Menuju Sejarah Kritis dan Sunan Prawoto Cucu Sunan Kalijogo. Adapun sumber lisan dari penelitian ini yaitu hasil wawancara yang dilakukan oleh peneliti kepada beberapa narasumber untuk memperoleh cerita rakyat yang tidak ada di dalam kedua sumber tulis tersebut.

Pengumpulan data yang dilakukan dalam penelitian ini menggunakan beberapa teknik yaitu observasi, dokumentasi, dan perekaman. Observasi dilakukan oleh peneliti sejak awal melakukan penelitian, bertujuan untuk mengamati dan mempelajari daerah penelitian. Kemudian peneliti menentukan sumber data yang akan diteliti melalui dokumentasi dan perekaman. Teknik dokumentasi dalam penelitian ini ialah mendokumentasi sumber data tulis yang berupa buku kumpulan cerita rakyat Kabupaten Pati sebagai dokumen cerita rakyat yang akan diteliti. Teknik perekaman dilakukan untuk beberapa cerita rakyat yang tidak ada di dalam sumber tulis tapi diketahui ada di masyarakat. Teknik perekaman yang dilakukan ialah perekaman audio terhadap narasumber yang menceritakan secara runtut. Hasil rekaman tersebut ditranskripsikan sehingga menjadi bahan tertulis.

Dalam penelitian ini, teori yang digunakan untuk menganalisis data yaitu teori sastra profetik yang berfokus pada etika humanisme. Beberapa langkah yang dilakukan oleh peneliti dalam menganalisis data yaitu: (1) membaca populasi data cerita rakyat di Kabupaten Pati yang berjumlah 12 cerita rakyat, (2) mengidentifikasi dan mengklasifikasi cerita rakyat yang mengandung etika humanisme sebagai sampel data, (3) menganalisis sampel data yang menunjukkan etika humanisme di dalam cerita rakyat, (4) menganalisis sampel data yang menunjukkan faktor tokoh melakukan etika humanisme di dalam cerita rakyat, (5) menarik kesimpulan dari hasil analisis cerita rakyat di Kabupaten Pati.

\section{HASIL PENELITIAN}

Hasil penelitian humanisme dalam cerita rakyat di Kabupaten Pati disajikan ke dalam dua bagian permasalahan, meliputi: (1) bentuk etika humanisme dalam cerita rakyat di Kabupaten Pati, (2) faktor yang melatarbelakangi tokoh beretika humanisme.

1) Bentuk Etika Humanisme dalam Cerita Rakyat di Kabupaten Pati

a) Kerja Sama (cerita rakyat Adipati Pragola I)

Sebagai makhluk sosial, manusia satu dengan manusia lainnya saling membutuhkan untuk berinteraksi, salah satunya saling untuk kerja sama. Kerja sama adalah kegiatan atau usaha yang dilakukan oleh dua orang atau dua kelompok orang atau lebih untuk mencapai tujuan bersama. Berikut adalah kutipan yang menunjukkan etika kerjasama:

Hubungan Joyokusumo dengan Panembahan Senopati berjalan cukup harmonis. Mereka bahu membahu dalam perang mengalahkan musuhmusuh Mataram, salah satunya dalam perang di Madiun. (Sejarah Masyarakat Pati: Dari Tradisi Lisan Menuju Sejarah Kritis. 2014. Hal 62)

Setelah Penjawai dan Pemanahan wafat, hubungan anak-anak merka, Joyokusumo dengan Panembahan Senopati tetap berjalan harmonis. Mereka bahu membahu dalam perang mengalahkan musuh- 
musuh Mataram, salah satunya dalam perang di Madiun.

b) Belas Kasihan (cerita rakyat Brubuh Majasemi)

Belas kasihan adalah etika humanisme seseorang yang muncul ketika indranya menangkap ada sesuatu yang membuat hatinya berempati. Seseorang yang memiliki perasaan belas kasihan terhadap sesama artinya peduli dan tidak acuh terhadap beban atau masalah yang dimiliki seseorang. Orang yang berbelas kasihan kemungkinan besar akan membantu menyelesaikan masalah seseorang yang dibelaskasihani. Berikut adalah kutipan yang menunjukka etika belas kasihan:

Tidak tega melihat tiga perempuan yang dibawanya kehausan di tengah musim kemarau yang panjang, Ki Soponyono mencuri beberapa buah mentimun dan ladang milik panewu Sukmoyono. Raden Kembangjoyo yang kebetulan telah menunggui ladang kakaknya, memergoki Soponyono. Perkelahian pun terjadi dan ki Soponyono rubuh.

(Sejarah Masyarakat Pati: Dari Tradisi Lisan Menuju Sejarah Kritis. 2014. Hal 57-58)

Etika belas kasihan dalam cerita rakyat Brubuh Majasemi ditunjukkan oleh tokoh Soponyono dan Sukmoyono. Belaskasihan Soponyono ditunjukkan saat ia merasa kasihan pada Ambarsari, Ambarwati, dan Dewi Rayungwulan yang dalam pelariannya sudah terlihat kelelahan. Rasa kasihan soponyono mendorong dirinya untuk mencuri buah mentimun di Ladang Sukmoyono, yang saat itu dijaga adiknya, Kembangjoyo.

c) Cakap dan Cekatan (cerita rakyat Prahara di Bumi Pati: Wasis Joyo Kusumo II)

Cakap merupakan kemampuan melakukan sesuatu dengan baik di dalam suatu bidang. Manusia yang cakap dan cekatan berarti memiliki kepandaian dalam melakukan hal-hal yang baik dan bermanfaat bagi manusia. Di bawah ini merupakan kutipan yang menunjukkan tokoh beretika cakap dan cekatan:

Dengan cepat keampuhan Pragola II diakui melalui strateginya memperluas wilayah Pati dengan melantik enam
Bupati Pati yang setia kepadanya. Keadaan tersebut membuat Tumenggung Endratara merasa tidak senang dan menghasut Sultan Agung, bahwa suatu saat Pati akan menyerang Mataram.

(Sejarah Masyarakat Pati: Dari Tradisi Lisan Menuju Sejarah Kritis. 2014. Hal 64)

Sikap Cakap dan cekatan ditunjukkan oleh Adipati Pragolo II saat dilantik meneruskan posisi ayahnya sebagai Adipati Pati. Pragola II diakui mampu menjadi penguasa Pati melalui strateginya memperluas wilayah Pati dengan melantik enam Bupati Pati yang setia kepadanya.

d) Rukun dan Bekerjasama (cerita rakyat Nyai Ageng Bakaran)

Manusia merupakan makhluk sosial yang membutuhkan interaksi dengan manusia lainnya, salah satunya ialah kerja sama. Manusia perlu melakukan kerja sama untuk mendapatkan suatu hal dengan hasil yang maksimal. Dengan bekerjasama maka terjalinlah kerukunan di antara manusia. Berikut kutipan yang menunjukkan etika rukun dan bekerja sama:

Setelah kejadian tersebut, Nyai Ageng Bakaran memilih membangun kerja sama dengan kakaknya di Dhukut Alit. Bersama-sama kedua desa membangun tambak ikan dan keduanya makmur. Kemakmuran ini diikuti dengan kebiasaan Nyai Ageng Bakaran memelihara ayam lurik dan menyabungnya. Sabung ayam pun menjadi kegiatan yang sangat disukai di Desa Bakaran. (Sejarah Masyarakat Pati: Dari Tradisi Lisan Menuju Sejarah Kritis. 2014. Hal 50)

Etika rukun dan bekerjasama dalam cerita rakyat Nyai Ageng Bakaran ditunjukkan oleh Nyai Sabirah dan kakaknya, Ki Dhukut. Dalam cerita tersebut dikisahkan bahwa Nyai sabirah bersama kakaknya kerjasama membangun tambak ikan dan keduanya makmur.

e) Berwawasan Luas (cerita rakyat Syaikh Jangkung)

Seseorang yang memiliki banyak ilmu pengetahuan dan tahu 
penggunaan/penerapan dari ilmu yang dimilikinya tersebut merupakan orang yang berwawasan luas. Seorang yang berwawasan luas sangat bermanfaat bagi orang lain, karena keilmuan yang dimilikinya dapat memajukan umat manusia. Berikut kutipan yang menunjukkan etika berwawasan luas:

Jangkung tak hanya dikenal sakti namun juga pandai berlayar, berdiplomasi,dan seorang ahli agama. (Sejarah Masyarakat Pati: Dari Tradisi Lisan Menuju Sejarah Kritis. 2014. Hal 68)

Dalam cerita rakyat Syekh Jangkung, Saridin dikenal sebagai sosok yang pintar, cerdas, dan juga cerdik. Ia pandai berdiplomasi dan pandai menyelesaikan masalah. Ia juga dikenal sebagai seorang ahli agama.

f) Bijaksana (cerita rakyat Syaikh Ahmad Mutamakin)

Bijaksana adalah sikap tepat dalam menyikapi setiap keadaan dan pertistiwa sehingga memancarlah keadilan. Orang yang bijaksana selalu mengambil keputusan setelah melalui pemikiran yang panjang berdasarkan pengetahuan dan pengalaman. Berikut adalah kutipan yang menunjukkan etika bijaksana :

Syekh Ahmad Mutamakin pun dipangil ke Keraton Kartasura untuk disidang. Ia dituduh menyimpangkan ajaran agama Islam dan diancam hukumna pancung. Akan tetapi, perdebatan yang tak kunjung usai menghasilkan jalan buntu di pengadilan. Pada akhirnya, Raja Kartasura berniat menguji kebijaksanaan Syekh Ahmad Mutamakin seorang diri dengan menyuruhnya menafsirkan mimpi. Oleh Sang Raja, Syekh Ahmad Mutamakin diputuskan bebas. Di lain pihak, Khotib Anom merasa keberatan sehingga harus dilakukan penilaian ulang melalui pertandingan tasir mimpi Dewa Ruci. Syekh Mutamakin memenangkan tafsiran tersebut dan mendapat wilayah perdikan Kajen. (Sejarah Masyarakat Pati: Dari Tradisi Lisan Menuju Sejarah Kritis. 2014. Hal 70-71)

Aspek bijaksana dalam cerita rakyat Syekh Ahmad Mutamakin tidak diceritakan detail. Aspek tersebut diketahui dari keterangan penulis bahwa Mutamakin berhasil melalui tes kebijaksanaan sehingga ia lolos dari hukuman. g) Menyayangi Keluarga (Cerita Rakyat Wafatnya Sunan Prawoto)

Menyayangi keluarga merupakan sikap baik yang patut untuk dicontoh. Sikap saling menyayangi dalam keluarga selain dapat menumbuhkan suasana harmonis juga akan memberikan efek yang positif untuk perkembangan mental sang anak. Berikut adalah kutipan yang menunjukkan etika menyayangi keluarga dalam cerita rakyat Wafatnya Sunan Prawoto :

"sudah selayaknya hutang harus dibayar. Laksanakan saja tugas kalian. Jika hutang itu ada padaku, jangan sampai istriku dan jabang bayi yang dikandung itu ikut menanggung hutangku juga" jawab Ki Ageng Tompe. Maka salah seorang suruhan tersebut menghunus keris brongot setan kober yang telah dibawa dari Aryo Penangsang dan menancapkan ke perut Ki Ageng Tompe. Karena saat menancapkan terlalu keras, keris tersebut menembus perut Istri ki Ageng Tompe hingga terlihat si jabang bayi. Melihat istrinya bersimbah darah, Ki Ageng Tompe murka dan menghunus kerisnya lalu dilempar ke kedua orang tersebut. Soreng Pati yang terluka parah meninggal tak jauh dari pesanggrahan Sunan Prawoto, sementara Soreng Rangkut bisa kembali sampai kudus. (Suprat, wawancara, 12 Januari 2018)

Etika menyayangi keluarga dalam kutipan tersebut ditunjukkan oleh tokoh Ki Ageng Tompe, yaitu ketika Ki Ageng Tompe meminta pada Soreng Pati dan Soreng Rangkut agar tidak melukai istri dan anaknya yang masih berada dalam kandungan. Karena yang dianggap hutang adalah $\mathrm{Ki}$ Ageng Tompe, ia tidak ingin istri dan anaknya terlibat untuk membayar hutangnya. Namun Soreng Pati dan Soreng Rangkut justru tanpa disengaja melukai istrinya, maka murkalah $\mathrm{Ki}$ Ageng tompe, dan menghunus kerisnya untuk melukai Soreng Pati dan Rangkut.

h) Baik Hati (Cerita Rakyat Raden Sahid)

Baik hati yaitu sikap aktif yang dilakukan untuk membantu orang lain dengan ramah dan berguna. Berikut 
adalah kutipan yang menunjukkan etika baik hati:

Ki Ageng merto yang menjumpai Ki Ageng Tompe sudah bersimbah darah berusaha menolongnya, namun tidak bisa menyelamatkan nyawanya. Sebelum meninggal, Ki Ageng Tompe meminta $\mathrm{Ki}$ Ageng Merto untuk merawat anaknya dan memberi nama Raden Sahid. Nama tersebut diambil dari Ibunya yang meninggal dengan sahid. Ki Ageng Merto mematuhi permintaan $\mathrm{Ki}$ Ageng Tompe. Ia merawat Raden Sahid hingga dewasa. (Suprat, wawancara, 12 Januari 2018)

Dalam kutipan tersebut, sikap baik hati ditunjukkan oleh tokoh $\mathrm{Ki}$ Ageng Merto. Meskipun ia tidak bisa menyelamatkan nyawa Ki Ageng Tompe beserta istrinya, Ki Ageng Merto bersedia merawat Raden Sahid dari bayi hingga dewasa.

2) Faktor yang Melatarbelakangi Tokoh Beretika Humanisme

a) Faktor Internal

Faktor internal, yaitu faktor yang berwujud insting atau naluri yang berasal dari dalam diri seseorang dan dimiliki sejak lahir tanpa ada campur tangan dari pihak lain.

Etika belaskasihan yang terdapat dalam cerita rakyat Brubuh Majasemi merupakan etika humanisme dilatar belakangi oleh faktor internal. Etika belas kasihan dalam cerita rakyat Brubuh Majasemi ditunjukkan oleh tokoh Soponyono dan Sukmoyono. Naluri belaskasihan Soponyono ditunjukkan saat ia merasa kasihan pada Ambarsari, Ambarwati, dan Dewi Rayungwulan yang dalam pelariannya sudah terlihat kelelahan. Rasa kasihan soponyono mendorong dirinya untuk mencuri buah mentimun di Ladang Sukmoyono, yang saat itu dijaga adiknya, Kembangjoyo. Berikut adalah kutipannya:

Tidak tega melihat tiga perempuan yang dibawanya kehausan di tengah musim kemarau yang panjang, Ki Soponyono mencuri beberapa buah mentimun dan ladang milik panewu Sukmoyono. Raden Kembangjoyo yang kebetulan telah menunggui ladang kakaknya, memergoki Soponyono. Perkelahian pun terjadi dan ki Soponyono rubuh. $K i$ Soponyono beserta kedua adiknya, dan
Dewi Rayungwulan dibawa kehadapan Sukmoyono. Untaian kisah terlantun dari mulut Soponyono hingga akhirnya mereka tiba di Majasemi. (Sejarah Masyarakat Pati: Dari Tradisi Lisan Menuju Sejarah Kritis. 2014. Hal 5758)

Sikap cakap dan cekatan yang dimiliki oleh Joyokusumo II merupakan etika humanisme yang dilatarbelakangi oleh faktor internal juga. Dengan cepat keampuhan Pragola II diakui melalui strateginya memperluas wilayah Pati dengan melantik enam Bupati Pati yang setia kepadanya. Keadaan tersebut membuat Tumenggung Endratara merasa tidak senang dan menghasut Sultan Agung, bahwa suatu saat Pati akan menyerang Mataram. (Sejarah Masyarakat Pati: Dari Tradisi Lisan Menuju Sejarah Kritis. 2014. Hal 64)

Dari kutipan tersebut, dapat diketahui naluri dan insting Joyokusumo II dalam membaca situasi untuk memajukan Pati diwujudkan dengan mempercepat perluasan wilayah Pati serta melantik enam bupati yang setia kepadanya.

Faktor internal selanjutnya juga melatarbelakangi etika berwawasan luas dalam cerita rakyat Syeikh Jangkung yang ditunjukka oleh tokoh Saridin. Saridin atau Syeikh Jangkung dikenal sebagai sosok yang pintar, cerdas, dan juga cerdik. Sebagai seorang tokoh, tentu nalurinya mengantarnya untuk selalu mampu menjadi pengayom bagi masyarakat. Hal ini ditunjukkan bahwa Syeikh Jangkung pandai berdiplomasi dan pandai menyelesaikan masalah. Ia juga dikenal sebagai seorang ahli agama. Berikut adalah kutipan yang menunjukkan etika berwawasanluas yang dimiliki oleh Syeikh Jangkung:

Jangkung tak hanya dikenal sakti namun juga pandai berlayar, berdiplomasi,dan seorang ahli agama. (Sejarah Masyarakat Pati: Dari Tradisi Lisan Menuju Sejarah Kritis. 2014. Hal 59)

Etika bijaksana yang terdapat dalam cerita rakyat Syeikh Ahmad Mutamakin juga dilatarbelakangi faktor internal. Meskipun tidak diceritakan secara jelas bentuk kebijaksanaannya, namun diketahui bahwa kebijaksanaan tersebut merupakan sikap alamiah yang terdapat dalam diri 
Ahmad Mutamakin sebagai pribadi seorang tokoh ahli agama. Berikut adalah kutipan kebijaksanaan yang dimiliki oleh Ahmad Mutamakin:

Pada akhirnya, Raja Kartasura berniat menguji kebijaksanaan Syekh Ahmad Mutamakin seorang diri dengan menyuruhnya menafsirkan mimpi. Oleh Sang Raja, Syekh Ahmad Mutamakin diputuskan bebas. Di lain pihak, Khotib Anom merasa keberatan sehingga harus dilakukan penilaian ulang melalui pertandingan tasir mimpi Dewa Ruci. Syekh Mutamakin memenangkan tafsiran tersebut dan mendapat wilayah perdikan Kajen. (Sejarah Masyarakat Pati: Dari Tradisi Lisan Menuju Sejarah Kritis. 2014. Hal 70-71)

Etika humanisme yang dilatarbelakangi faktor internal selanjutnya adalah etika menyayangi keluarga. Etika menyayangi kelurga terdapat dalam cerita rakyat Wafatnya Sunan Prawoto, yaitu ketika Ki Ageng Tompe meminta agar Soreng Pati dan Soreng Rangkut tidak melukai istri dan anak yang berada dalam kandungan istrinya. Manakala istrinya ikut dilukai, maka Ki Ageng Tompe murka dan menghunus kerisnya dan melempar pada Soreng Pati dan Soreng Rangkut hingga mereka terluka dan tewas. Berikut adalah kutipannya:

"sudah selayaknya hutang harus dibayar. Laksanakan saja tugas kalian. Jika hutang itu ada padaku, jangan sampai istriku dan jabang bayi yang dikandung itu ikut menanggung hutangku juga" jawab Ki Ageng Tompe. Maka salah seorang suruhan tersebut menghunus keris brongot setan kober yang telah dibawa dari Aryo Penangsang dan menancapkan ke perut Ki Ageng Tompe. Karena saat menancapkan terlalu keras, keris tersebut menembus perut Istri ki Ageng Tompe hingga terlihat si jabang bayi. Melihat istrinya bersimbah darah, Ki Ageng Tompe murka dan menghunus kerisnya lalu dilempar ke kedua orang tersebut. Soreng Pati yang terluka parah meninggal tak jauh dari pesanggrahan Sunan Prawoto, sementara Soreng Rangkut bisa kembali sampai kudus. (Suprat, wawancara, 12 Januari 2018)

Sikap sayang terhadap keluarga yang ditunjukkan oleh Ki Ageng Tompe tersebut merupakan sikap naluriah yang muncul dari hati nurani seorang suami yang ingin membela istri dan anaknya. Maka layak bagi Ki Ageng Tompe bila murka dan menghunuskan keris kepada orang yang telah melukai istrinya.

Etika humnisme yang dilatarbelakangi oleh faktor internal selanjutnya adalah baik hati, yang terdapat dalam cerita rakyat Raden sahid. Etika baik hati dalam cerita tersebut ditunjukkan oleh tokoh Ki Ageng Merto yang bersedia merawat anak Ki Ageng Tompe dari bayi hingga dewasa. Berikut adalah kutipannya:

Ki Ageng merto yang menjumpai $\mathrm{Ki}$ Ageng Tompe sudah bersimbah darah berusaha menolongnya, namun tidak bisa menyelamatkan nyawanya. Sebelum meninggal, Ki Ageng Tompe meminta Ki Ageng Merto untuk merawat anaknya dan memberi nama Raden Sahid. Nama tersebut diambil dari Ibunya yang meninggal dengan sahid. Ki Ageng Merto mematuhi permintaan Ki Ageng Tompe. Ia merawat Raden Sahid hingga dewasa. (Suprat, wawancara, 12 Januari 2018)

Dalam kutipan tersebut $\mathrm{Ki}$ Ageng Merto menunjukkan bahwa sikap baik hatinya tulus dari hati untuk merawat Raden Sahid dari kecil hingga dewa.

b) Faktor Eksternal

(1) Desakan Situasi

Kerja sama yang terjalin antara Mataram dan Pati seperti yang diceritakan dalam cerita rakyat Adipati Pragola I merupakan sikap yang dilatarbelakangi oleh faktor situasi dan kondisi yang telah diwarisi seacara turun temurun. $\mathrm{Ki}$ Pemanahan dan putranya, Sutawijaya mengembangkan alas mentaok hingga besar menjadi Mataram. Sedangkan Ki Penjawi memimpin Pati. Setelah Ki Pemanahan dan Ki Penjawi wafat, kekuasaan diwariskan pada putranya masing-masing. Mataram dipimpin oleh Sutawijaya yang akhirmya mendapat gelar Panembahan Senopati, dan Pati dipimpin oleh Joyokusuma yang bergelar adipati Pragolo I. Hubungan Joyokusumo dengan Panembahan Senopati 
berjalan cukup harmonis. Mereka bahu membahu dalam perang mengalahkan musuh-musuh Mataram, salah satunya dalam perang di Madiun. Berikut adalah kutipannya:

Hubungan Joyokusumo dengan Panembahan Senopati berjalan cukup harmonis. Mereka bahu membahu dalam perang mengalahkan musuhmusuh Mataram, salah satunya dalam perang di Madiun. (Sejarah Masyarakat Pati: Dari Tradisi Lisan Menuju Sejarah Kritis. 2014. Hal 62)

Kerja sama yang terjalin antara Pati dan Mataram dikarenakan adanya hubungan yang sudah diikat secara turun temurun, yaitu ditandai dengan pernikahan antara Panembahan Senopati dengan Rorosari.

(2) Lingkungan

Etika selanjutnya adalah rukun dan kerjasama. Rukun dan kerjasama yang ditunjukkan oleh Nyai Ageng Bakaran dan Kakaknya dalam cerita rakyat Nyai Ageng Bakaran dilatarbelakangi oleh faktor lingkungan. Berikut kutipannya:

Setelah kejadian tersebut, Nyai Ageng Bakaran memilih membangun kerja sama dengan kakaknya di Dhukut Alit. Bersama-sama kedua desa membangun tambak ikan dan keduanya makmur. Kemakmuran ini diikuti dengan kebiasaan Nyai Ageng Bakaran memelihara ayam lurik dan menyabungnya. Sabung ayam pun menjadi kegiatan yang sangat disukai di Desa Bakaran, hingga pada suatu hari seorang pelayar dari Cina tertarik untuk melihat sendiri ayam lurik Nyai. Sang pelayar bermaksud menantang ayam lurik Nyai menggunakan seekor ayam jago berwarna putih bernama ayam Siyem yang dibuat dari palu dibungkus kain putih. (Sejarah Masyarakat Pati: Dari Tradisi Lisan Menuju Sejarah Kritis. 2014. Hal 50)

Dalam cerita tersebut dikisahkan bahwa Nyai Sabirah bersama kakaknya berkerjasama membangun tambak ikan dan keduanya makmur. Dikisahkan sebelumnya bahwa kakak beradik ini menunjukkan sikap rukun dan bekerja sama sejak mereka membuka hutan untuk ditempattinggali. Kerja sama antar keduanya ini terus ditunjukkan bahkan ketika pemukiman yang mereka buka sudah ramai oleh penduduk, yakni bekerjasama membuat tambak ikan. Kerja sama membuka tambak ikan tentu bukan tanpa alasan, hal ini dikarenakan lingkungan yang mereka tinggali cocok untuk bertani ikan. Dikisahkan bahwa pemukiman yang mereka buka berada di dekat danau.

\section{SIMPULAN}

Berdasarkan pembahasan pada bab sebelumnya, maka simpulan yang dapat dikemukakan adalah pertama, bentuk etika humanisme yang terdapat dalam cerita rakyat di Kabupaten Pati yaitu etika kerja sama, belaskasihan, cakap dan cekatan, rukun dan kerja sama, berwawasan luas, bijaksana, menyayangi keluarga, dan baik hati. Kedua faktor yang melatarbelakangi tokoh beretika humanisme dikemukakan terdapat dua faktor, yaitu faktor internal dan faktor eksternal. Faktor internal melatarbelakangi etika belaskasihan, cakap dan cekatan, berwawasan luas, dan bijaksana, menyayangi keluarga, dan baik hati. Selanjutnya, faktor eksternal dibagi menjadi dua faktor, yaitu faktor desakan situasi dan faktor lingkungan. Faktor situasi melatarbelakangi etika kerja sama dan baik hati, dan faktor lingkungan melatarbelakangi etika rukun dan kerjasama.

Berdasarkan simpulan yang telah dikemukakan di atas, maka saran yang dapat diberikan sebagai berikut:

Pertama, pembaca diharapkan dapat menggunakan cerita rakyat sebagai salah satu alat penumbuh rasa kemanusiaan di antara sesama manusia melalui aspek-aspek humanisme yang sudah dikemukakan pada pembahasan sebelumnya. Kedua, para peneliti sastra diharapkan menggunakan penelitian ini sebagai acuan untuk melakukan penelitian selanjutnya, khususnya penelitian folklor dan penelitian sastra profetik.

\section{DAFTAR PUSTAKA}

Afianti, Irma Yuliana. 2016. Pandangan Dunia Humanisme Religius dalam Trilogi Novel Negeri 5 Menara Karya Ahmad 
Fuadi. Tesis. Universitas Negeri Semarang.

Kuntowijoyo. 2013. Maklumat Sastra Profetik: Kaidah Etika dan Struktur Sastra. Yogyakarta: Multi Presindo.

Lestari, Agustina Tri. 2009. Cerita Dewi Rayung Wulan dalam Serat Babad Pati. Skripsi. Universitas Negeri Semarang

Lukin, Karima. 2009. "Nenets Folklore in Russian: The Movement of Culture in Forms and Languages". Journal of Ethnology and Folkloristics. Vol. 2. Nomor 1: 67-82. Estonia: University of Tartu.

Margana, Sri dan Baha'udin. 2014. Sejarah Masyarakat Pati: Dari Tradisi Lisan Menuju Sejarah Kritis. Pati: Kantor Arsip dan Perpustakaan Daerah Pati.

Moleong, L. 2007. Metode Penelitian Kualitatif. Bandung: PT.Remaja Rosdakarya.

Prasetyo, Heru. 2009. Struktur Naratif Cerita Baron Sekeber dalam Serat Babd Pati. Skripsi. Universitas Negeri Semarang

Qomariyah, U'um. 2015. "Membaca Empat Novel Habiburrahman El-Shirazy: Internalisasi Pengembangan Nilai Profetik Berbasis Karakter". Prosiding I Seminar Internasional Bahasa, Sastra, dan Pembelajarannya: Pengembangan Nilainilai Profetik dalam Kehidupan Berbangsa melalui Bahasa, Sastra, dan Pembelajarannya. Hlm. 339-345. Malang: Universitas Muhammadiyah Malang.

Suheyla, Saritas. 2008. "MATERIAL CULTURE OBJECTS IN THE EPICS OF DEDE KORKUT AND ÂȘIK GARIP FOLK ROMANCE". Turkish Studies: International Periodical For the Languages, Literature and History of Turkish or Turkic. Volume 3/1. Turkey: ASOS Eğitim Bilișim Danıșmanlık.

Suprat interview. 2018. "Wawancara Cerita Rakyat di Kabupaten Pati". Pati

Trianton, Teguh. 2013. "Estetika Profetik Ahmad Tohari Dalam Khazanah Budaya Cablaka". IBDA': Jurnal Kebudayaan Islam. Indonesia: LPPM IAIN Purwokerto. 